\title{
8 When Bad Labour Conditions Become Exploitation
}

\author{
Lessons Learnt from the Chowdury Case
}

Conny Rijken

\begin{abstract}
This chapter explains how exploitation is related to practices of slavery, forced and compulsory labour, and trafficking in human beings. Understanding the different types and levels of abuse of workers and how such practices are legally qualified help to distinguish between bad labour conditions and exploitation. Rijken pays special attention to the recent case of Chowdury et al., vs Greece in which the European Court of Human Rights (ECtHR) clarified some aspects related to forced labour but left others untouched. Based on the concepts of consent, coercion, and vulnerability, Rijken provides a framework that can be used to determine when a situation is qualified as exploitation.
\end{abstract}

Keywords: labour exploitation, forced labour, Chowdury case, slavery, human trafficking

\section{Introduction}

Decent work can turn into bad labour and bad labour can degenerate into labour exploitation. A situation of labour exploitation is not static, nor are bad labour and decent work. Migrant workers, especially those at the low end of the labour market, are more prone to end up in a situation of exploitation caused by a complex array of (interrelated) factors, such as labour market demands for flexibility and migration opportunities, which

Rijken, Conny and Tesseltje de Lange (eds): Towards a Decent Labour Market for Low Waged Migrant Workers. Amsterdam: Amsterdam University Press, 2018 DOI: 10.5117/9789462987555_RIJK 
flourish in today's globalised world. ${ }^{1}$ When migrant workers are in the host country for only a limited period of time, it is more difficult for them to become familiar with their (labour) rights, to execute these rights, and they have fewer chances to be subjected to control by monitoring bodies. ${ }^{2}$ Because of a lack of job opportunities and dire economic situations in their home countries, migrants may be willing to try their chances in another country, even under bad working conditions. These factors increase their vulnerability to be exploited. Apart from this more or less voluntary entry into exploitative working conditions, the exploitation of a person can also imply explicit involuntariness, pressure, and even force. The term 'exploitation' is easily used to point at practices in which labour laws are violated. In legal terms, however, it is not clear when bad labour practices qualify as exploitation. ${ }^{3}$ On both national and international levels, academics, legislators, and practitioners struggle to clarify this term. In some countries, exploitation of persons, as such, is a criminal offence, while, in many other countries, exploitation is seen as the negative outcome or intent of the crime of human trafficking. Whether and how exploitation is related to practices of slavery, forced and compulsory labour, and trafficking in human beings still needs further scrutiny. This chapter aims to contribute to this process and will explain the different types and levels of abuse of workers and how such practices are legally qualified. It argues that exploitation is an overarching term including different forms of abuse in labour situations and a practice at the very end of the continuum of decent work, bad labour conditions, and exploitation. It will pay special attention to the recent case of Chowdury et al., vs Greece, in which the European Court of Human Rights (ECtHR) clarified some aspects of the discussion but left others untouched. Another important development at the international level is the adoption of the protocol to the Convention on forced and compulsory labour adopted by the ILO in 2014. The added value of this protocol will also be addressed in this chapter. First, the legal definition of labour exploitation

1 B. Anderson and J. O'Connell Davidson (2003), Trafficking - A Demand Led Problem? A Multi Country Pilot Study, International Organisation for Migration; A. van den Anker and I. van Liempt (eds.) (2012), Human Rights and Migration. Trafficking for Forced Labour, Palgrave Macmillan; H. F. Chang (2008), 'The Economics of International Labour Migration and the Case for Global Distributive Justice in Liberal Political Theory', Cornell International Law Journal, p. 1.

2 D. Mccann and J. Fudge (June 2017), 'Unacceptable forms of work: A multidimensional mode', in International Labour Review, 156(2) pp.147-184.

3 European Agency on Fundamental Rights (FRA) published its report (2015) Severe Labour Exploitation: Workers Moving within or into the European Union, States' Obligations and Victims' Rights. 
will be explored, followed by a discussion of the Chowdury case. The chapter continues with the factors that determine the dividing line between bad labour conditions and exploitation. The reasons to distinguish between these two are: first, because practices of exploitation are a criminal offence in most jurisdictions, which implies competences for law enforcement authorities. Bad labour conditions are most often considered violations of labour law. Second, because exploitation is the detrimental outcome or the very aim of human trafficking and combating it implies specific obligations to protect its victims and to prevent the phenomenon.

\section{Labour Exploitation: Forced Labour, Slavery, and Servitude}

The term (labour) exploitation is often used, but rarely defined. ${ }^{4}$ In some countries, a mere violation of labour rights is considered exploitation, whereas, in other countries, only cases of severe violation qualify as such, albeit without further defining such severity. ${ }^{5}$ Questions as to whether or not coercion is a constitutive element of exploitation and whether or not exploitation exists or can exist if the worker has 'consented' to the long working hours or low pay, are addressed differently in different jurisdictions. ${ }^{6}$ What conduct or circumstances constitute exploitation is not consistently understood and is dependent on how situations are framed in national legislation. ${ }^{7} \mathrm{~A}$ lack of criteria for determining the existence of exploitation further contributes to this conceptual indistinctness.

Labour exploitation can be the objectionable outcome of the trafficking process and, therefore, is often related to human trafficking. ${ }^{8}$ In order

4 UNODC issue paper (2015), The Concept of 'Exploitation' in the Trafficking in Persons Protocol, pp. 24-26.

5 International Labour Organization (2009), Forced Labour and Human Trafficking. Casebook of Court Decisions. Special Action Programme to Combat Forced Labour.

6 V. Ottonelli and T. Torresi (2013), 'When is Migration Voluntary?', International Migration Review, 47 pp. 783-813; J.G. Pope (2010), 'A Free Labor Approach to Human Trafficking', University of Pennsylvania Law Review, 158 pp. 1849-1875; R. Steinfeld (2009), Coercion/Consent in Labour, Centre on Migration, Policy and Society, Working Paper No. 66, University of Oxford; M. Szulecka (2012), 'The Rights to be Exploited: Vietnamese Workers in Poland', in C. van den Anker and I. van Liempt (eds.), Human Rights and Migration. Trafficking for Forced Labour, Palgrave Macmillan. 7 B. Anderson (2010), 'Migration, immigration controls and the fashioning of precarious workers', Work, Employment and Society, 24(2) pp. 300-317; J. O'Connell Davidson (2013), 'Troubling freedom: migration, debt, and modern slavery', Migration Studies, pp. 1-20.

8 Article 3 of the Trafficking Protocol defines human trafficking as: the recruitment, transportation, transfer, harbouring or receipt of persons, by means of the threat or use of force or other forms of coercion, of abduction, of fraud, of deception, of the abuse of power or of a position 
to identify the dividing line between bad labour conditions and labour exploitation, it is not only relevant to elucidate terminological ambiguity, but it also helps to clarify in which situations the anti-trafficking legal framework (including provisions on protection of victims) can be triggered.

The term 'labour exploitation' regained attention when it was included in the definition on human trafficking in the Trafficking Protocol to the UN Convention on Transnational Organised Crime in 2000. ${ }^{9}$ Trafficking in human beings has long been associated with sexual exploitation and forced prostitution, but the Trafficking Protocol brought labour exploitation under the human trafficking umbrella. Without going into the nitty gritty of the definition of human trafficking, ${ }^{10}$ exploitation in the Trafficking Protocol has not been defined, but is instead described in Article 3(2):

Exploitation shall include, at a minimum, the exploitation of the prostitution of others or other forms of sexual exploitation, forced labour or services, slavery or practices similar to slavery, servitude or the removal of organs.

Hence, Article 3 only lists a number of situations, which, 'in any case', must be considered exploitation. It does not, however, indicate what factors determine 'exploitation'. As mentioned, forced labour or services, servitude, slavery, or practices similar to slavery are phenomena that fall within the scope of labour exploitation and we have to look into long-standing conventions addressing these topics to understand their content. ${ }^{11}$

Forced labour has been defined in the 29 ILO convention as: 'all work or service which is exacted from any person under the menace of any penalty

of vulnerability or of the giving or receiving of payments or benefits to achieve the consent of a person having control over another person, for the purpose of exploitation. Exploitation shall include, at a minimum, the exploitation of the prostitution of others or other forms of sexual exploitation, forced labour or services, slavery or practices similar to slavery, servitude or the removal of organs.

9 Protocol to the United Nations Convention against Transnational Organised Crime to Prevent, Suppress and Punish Trafficking in Persons, Especially Women and Children, 15 November 2000 UN Doc. A/RES/55/25.

10 J.A. Chuang (2014), 'Exploitation Creep and the Unmaking of Human Trafficking Law', The American Journal of International Law, 108 pp. 609-649; J. Allain (2008-2009), 'The Definition of Slavery in International Law', Howard Law Journal, 52 pp. 258-261. Also see various contributions in special issue, Anti-Trafficking Review (2015), issue 4.

11 Convention Concerning Forced or Compulsory labour (ILO no. 29) 39 UNTS 55, 1930; P 029 Protocol of 2014 to the forced labour convention, 1930; Slavery Convention of 1926, 25 September 1926, 6o LNTS 253. Supplementary Convention on the Abolition of Slavery, the Slave Trade, and Institutions and Practices Similar to Slavery, 7 September 1956, 226 UNTS 3. 
and for which the said person has not offered himself voluntarily'. ${ }^{12}$ The ILO later explained that preventing people from leaving their jobs also equals to forced labour and, furthermore, that what commenced as a voluntary situation can later turn into a situation of forced labour. ${ }^{13}$ In 2014, this convention was supplemented with a protocol attempting to explain the link between human trafficking and forced labour. The protocol reaffirms the definition of the 1930 Convention and states that 'therefore the measures referred to in this Protocol shall include specific action against trafficking in persons for the purposes of forced or compulsory labour'. This, however, does not elucidate how the connection between trafficking and forced labour must be understood, but it seems to imply that forced labour is a possible outcome of human trafficking, whereas, previously, human trafficking was seen by the ILO as a form of forced labour. It furthermore aims to establish similar protection for victims of forced labour as for victims of human trafficking. The protocol addresses three elements: prevention, protection of victims, and compensation to victims. According to the protocol, forced labour should be combatted by using criminal law, public law, and labour law.

Slavery is defined in the 1926 Slavery Convention as: 'the status or condition of a person over whom any or all of the powers attaching to the right of ownership are exercised.' ${ }^{14}$

Nowadays, the possibility to exercise legal ownership over a person has been abolished throughout the world. Still, factual ownership, people behaving as if they have ownership over another person e.g. by selling that person to someone else, still exists and is criminalised worldwide, and is qualified as (modern) slavery, human trafficking, or another serious offence..$^{15}$ The recent CNN reports about the selling of migrants in camps in Libya are proof of these practices. ${ }^{16}$ Interestingly, the Slavery Convention distinguished between slavery and the slave trade. The slave trade was defined as:

all acts involved in the capture, acquisition or disposal of a person with intent to reduce him to slavery; all acts involved in the acquisition of a slave with a view to selling or exchanging him; all acts of disposal by sale or exchange of a slave acquired with a view to being sold or exchanged, and, in general, every act of trade or transport in slaves.

13 ILO Working Paper Forced Labour: Definition, Indicators and Measurement, 2004.

14 Article 1(1), Slavery Convention of 1926, (25 September 1926), 6o LNTS 253.

15 J. Allain (2009), 'R v Tang: Clarifying the Definition of 'Slavery' in International Law', Melbourne Journal of International Law, 10(1).

16 Available at: http://edition.cnn.com/specials/africa/libya-slave-auctions. 
Similar to the earlier distinction made between human trafficking and exploitation in prostitution in the 1949 Convention $^{17}$, the exploitative practices (slavery and exploitation in prostitution) are the outcomes of the recruitment process (slave trade and human trafficking). With the adoption of the Trafficking Protocol, not only was exploitation in prostitution, other forms of sexual exploitation, and exploitation in labour merged into one definition, but the clear distinction between the recruitment process or the movement and actual exploitation was done away with. In the additional protocol to the Slavery Convention, the following practices were identified as practices similar to slavery: debt bondage, serfdom, forced marriage, women inheritance, and child exploitation.

Servitude is not defined in a separate treaty, but is prohibited, for instance, in Article 4 of the ECHR. In the case law of the EctHR, servitude is described as: a 'particularly serious form of denial of freedom', which includes, 'in addition to the obligation to perform certain services for others $[. .$.$] the$ obligation for the "serf" to live on another person's property and the impossibility of altering his condition'. ${ }^{18}$ As such, servitude is a practice between forced labour and slavery.

\section{Exploitation explained}

Understanding exploitation has led to important academic debates. In the context of human trafficking, Chuang criticises the trafficking definition because 'forced labour is recast as trafficking' and 'all trafficking is labelled as slavery', which, in her view, creates an 'exploitation creep'. She explains the debate on whether or not all forms of forced labour must be considered human trafficking rather than only those situations of forced labour preceded by an act as defined in the trafficking definition, 'recruitments, transportation, transfer, harbouring or receipt of persons'. By turning the focus on forced labour and qualifying it as human trafficking, the expertise of human rights lawyers and labour rights lawyers, rather than merely criminal law lawyers, were naturally exerted to combat human trafficking. More recently, the term of 'modern slavery' has been used to replace the term human trafficking. ${ }^{19}$ This is at odds with the human trafficking definition,

17 Article 1, Convention for the Suppression of the Traffic in Persons and of the Exploitation of the Prostitution of Others, 1949.

18 Case of Siliadin v. France, Application no. 73316/o1, 26 July 2005 para 123.

19 J. Allain and K. Bales (2012), 'Slavery and Its Definition', Global Dialogue, 14(2). 
which considers slavery and practices similar to slavery as examples of the exploitative purpose of human trafficking. Additionally, it seems overly dramatised to qualify less severe forms of trafficking as modern slavery. Furthermore, as we have seen above, slavery in the 1926 Convention is narrowly defined, and, even with the extended understanding of modern slavery as the factual exercise of ownership rather than a legal one, the concept of human trafficking must be understood to be broader than (modern) slavery. ${ }^{20}$ For the crime of trafficking to exist, three elements must be present, namely an act of recruitment, a means (e.g. force, abuse of position of vulnerability, or deception), and an aim of exploitation. It cannot merely be reduced to only the third element, e.g. slavery as a form of exploitation. ${ }^{21}$

Chuang further argues that 'existing labour and migration frameworks have proven inadequate to the task of protecting those at the bottom of the global labour hierarchy', which she considers a core task of in anti-trafficking law and policy regimes. She concludes by saying that;

trafficking is often labour migration gone horribly wrong and that it is at least partly due to the combination of tightened border controls, which have created a growing market for clandestine migration services, and lax labour laws, which permit employers and recruiters to coercively exploit their workers with impunity. ${ }^{22}$

Thus, the situation of labour exploitation must not be looked at in isolation but in the broader context of structural market dynamics and practices, labour policies, and migration policies that shape workers' vulnerability. For this reason, many scholars advocate a combined approach to trafficking as well as to labour exploitation of which a labour approach is a part. ${ }^{23}$

Labour exploitation not only takes place in a migratory setting, but also occurs in domestic situations. Nevertheless, the examples in this volume show that migrant workers and especially undocumented migrants and migrant workers in flexible contracts and at the low and of the labour market are more vulnerable to exploitative practices.

20 Chuang, J. A. (2014), 'Exploitation Creep and the Unmaking of Human Trafficking Law', The American Journal of International Law, 108 pp. 624-625.

21 Chuang (2014), pp. 631-632.

22 Chuang (2014), p. 639.

23 D. Mccann and J. Fudge (June 2017), 'Unacceptable forms of work: A multidimensional model', International Labour Review, 156(2), pp. 147-184; J.G. Pope (2010), 'A Free Labor Approach to Human Trafficking', University of Pennsylvania Law Review, $15^{8}$ pp. 1849-1875. 
To elucidate the elements of exploitation and related phenomena further, we now turn to discuss the recent case Chowdury and others v. Greece of March 2017 of the ECtHR. ${ }^{24}$

\section{The Case of Chowdury}

Manolada Region in Greece is well-known for its agriculture. Farmers make use of migrant workers who often do not possess residency or work permits (hereafter referred to as undocumented workers) for harvesting the fruits and vegetables. The case of Chowdury started in April 2013 when a group of 150 undocumented Bangladeshi workers were shot at when they protested because they were not being paid the salary they were promised, or were not paid at all. Over 30 workers were severely injured during the shooting. The workers had to work and live under abhorrent circumstances; they worked twelve hours a day in the fields watched by armed guards, they were promised 22 euros a day, but the salaries were not paid. They lived in sheds without toilets or running water. The case was brought before the national court, which acquitted the employers for human trafficking. The migrant workers were not completely powerless and deprived of freedom of movement and therefore the case could not qualify as human trafficking, according to the Greek court. The Greek court convicted the employers to pay the victims 43 euros each, for causing grievous bodily harm caused by the shootings, and for the unlawful use of firearms. Disappointed by the outcome at the national level, 42 Bangladeshi workers filed a case against Greece at the ECtHR for violation of the positive obligations under Article 4 ECHR, containing a prohibition of slavery, forced labour, and servitude. The migrants claimed they had been subjected to forced labour and human trafficking. The Court held Greece liable for violating Article 4(2), the prohibition of forced labour, and noted that the applicants' situation was one of human trafficking and forced labour, and that Greece failed in its positive obligations to prevent and investigate the situation as well as to protect the victims.

The Chowdury case is considered a landmark case because of the reasoning of the Court to qualify the situation as one of forced labour and human trafficking and because, by using the 'disproportionate burden' test, it helps 
us to distinguish between bad labour conditions and forced labour. The importance of the case will be discussed in seven points.

First, in para. 123, the Court held that restrictions upon freedom of movement cannot be a necessary element (a condition sine qua non) for qualifying a situation as forced labour (and as human trafficking). It responded to the Greek government that argued that this case is not a case of forced labour nor human trafficking because the migrant workers had the opportunity to leave, go out and go shopping when they were not at work. If such freedom and movement were also restricted, it could have amounted to situations of servitude or slavery.

Second, the Court considers the fact that applicants are undocumented migrants relevant to determine their position of vulnerability, especially because of the threats from the employer should they refuse to cooperate. The employer told the workers that they would not be paid or that they would be killed if they did not continue to work for him (para. 98). In addition, the Court took into account the fact that the workers felt obliged to continue to work, knowing that, if they stopped working, they would not receive the wages owed to them, especially considering that they had no other means of subsistence (paras. 95 and 97). In case of abuse of such a position of vulnerability, it cannot be claimed that the workers offered themselves voluntarily (para. 96). The absence of voluntariness in accepting a job is a requirement of forced labour under the ILO Convention 29 as we have seen above.

This ties into the third interesting aspect of the case, namely that the Court reconfirms that prior consent is not an obstacle to define a situation of forced labour. The Greek authorities considered that the workers had consented to the working conditions, as they had been informed of the conditions at the point of recruitment. The ECtHR, however, concluded that, given the circumstances of this case and especially the abuse of power and the position of vulnerability (i.e. undocumented migrants, risk of expulsion), deprived the prior consent from its meaning.

96. The Court further considers that where an employer abuses his power or takes advantage of the vulnerability of his workers in order to exploit them, they do not offer themselves for work voluntarily. The prior consent of the victim is not sufficient to exclude the characterisation of work as forced labour.

This is very much in line with how consent is understood in the context of human trafficking. In case any of the means listed in the trafficking 
definition are used, the consent given to the situation is irrelevant. ${ }^{25}$ Two NGOs, PICUM and AIRE Centre, in their joint intervention letter in the Chowdury case, consider an assessment of the level of 'control' exercised by the employer over the victim, the nature of the menace and the severity of the penalty, to be an essential element in defining forced labour. According to them, factors that are relevant for such assessment include violence, restriction of movement, debt bondage, withholding of wages, retention of passports, and threat of denunciation to authorities. ${ }^{26}$ Thus, the level of control is often determined by a form of coercion.

A fourth contribution of the Chowdury case is the fact that it clarified the 'disproportionate burden' test (fardeau disproportionné, para. 91) originally introduced in Van der Mussele v. Belgium. ${ }^{27}$ This test attempts to distinguish forced or compulsory labour in the context of forced labour and forced or compulsory labour in the context of one's position or duties in an ordinary work situation. Para. 37 of the van der Mussele case states:

This could be so in the case of a service required in order to gain access to a given profession, if the service imposed a burden which was so excessive or disproportionate to the advantages attached to the future exercise of that profession, that the service could not be treated as having been voluntarily accepted beforehand.

Thus, if the service or work required (in the case of Van der Mussele in order to become an advocate) is excessive or disproportionate compared to the advantages it generates, it must be considered as not voluntarily accepted and (if other elements are fulfilled) constitutes forced labour. Labour that is in the 'general interest, social solidarity and what is in the normal or ordinary course of affairs' and is not unreasonable or disproportionate cannot be considered as forced labour (para. 38-39 van der Mussele). In other words, it tries to define when a person is subjected to an 'excessive and disproportionate burden', justifying the qualification of forced labour. In Chowdury, the Court notes that, for such assessment, all circumstances

25 Article 3(b) Protocol to Prevent, Suppress and Punish Trafficking in Persons Especially Women and Children, supplementing the United Nations Convention against Transnational Organized Crime.

26 Submission for intervenors, The AIRE Centre (Advice for Individual Rights in Europe) and Platform for International Cooperation on Undocumented Migrants (PICUM), Application No. 21884/15, para 6. ILO Report, Human Trafficking and Forced Labour Exploitation Guidance for Legislation and Law Enforcement (2005) pp. 20-21.

27 ECtHR, Van der Mussele v. Belgium, Application No. 8919/80, 23 November 1983. 
of the case need to be taken into account. ${ }^{28}$ Therefore, the fact that migrants were undocumented, ran the risk of not being paid at all when leaving, and the risk of being arrested and deported contributed to their vulnerability and were taken into account by the court (para. 95-96).

Fifth, the court tries to explain the relation between forced labour and human trafficking but complicates a conceptual divide by referring to the concept of exploitation. Although it strengthens the relevance of the defining forced labour, servitude, and slavery as prohibited in Article 4 ECHR, this case does not further add to the relation between these concepts nor to how the concept of 'exploitation' fits in, as Stoyanova rightly pointed out in her blog post on this case. ${ }^{29}$

Sixth, this case points out that the obligations to protect and assist trafficking victims also apply to those who have been subjected to forced labour. Here, the Court follows its line of reasoning initiated in Rantsev, in which the Court decided that human trafficking falls within the scope of Article 4 ECHR. ${ }^{30}$ Furthermore, it is also in line with the protocol to the Forced Labour Convention that requires the equal treatment of victims of trafficking and forced labour.

Seventh, and, logically, in light of Article 2 ECHR, the obligations following from the ECHR including the positive obligations to protect, also apply to undocumented migrants present on the territory of a State and not only to those legally residing in a country.

\section{Bad Labour Conditions and Exploitation}

So far, we have discussed concepts and practices that are clear examples of exploitation: forced labour, slavery, modern slavery, and human trafficking. It is, however, more challenging to take a look at those situations that are less obviously qualified as exploitation. Such situations arise, for instance, when no force or coercion is used, when the labour migrant has consented to the low salary, horrible living conditions, and excessive working hours.

Labour exploitation is an overarching term and can be situated at the very end of the continuum of decent work, bad labour conditions, and

\footnotetext{
28 Very much in line with D. McCann and J. Fudge (June 2017), 'Unacceptable forms of work: A multidimensional model', International Labour Review, 156(2), pp.147-184.

29 V. Stoyanova, Irregular Migrants and the Prohibition of Slavery, Servitude, Forced Labour \& Human Trafficking under Article 4 of the ECHR, blog post available at: https://www.ejiltalk.org/ author/vladislavastoyanova/

30 ECtHR, Rantsev v. Cyprus and Russia, Application no. 25965/04, 7 January 2010.
} 
exploitation (including forced labour and human trafficking). ${ }^{31}$ Decent work can turn into bad labour conditions and bad labour conditions sometimes degenerate into exploitation. But when do violations of labour law qualify as labour exploitation? Consent, control (or coercion), and vulnerability are three relevant factors that can be distilled from the Chowdury case. Below, we will further explore these elements of consent, vulnerability, and control (or coercion) to distinguish between bad labour conditions and labour exploitation. The case of Chowdury made clear that consent is irrelevant in a case in which a person's situation of vulnerability is abused. It furthermore made explicit that restricting liberty to move can exist both in physical and psychological restriction. Chowdury, made clear that we need to consider the situation as a whole and assess every case individually. ${ }^{32}$ Furthermore, if circumstances imply an excessive or disproportionate burden for accessing a job, it must be considered forced labour. Logically, this equally applies during the execution of a job or when leaving a job. The next question, then, is when are circumstances excessive or disproportionate?

This question on excessive or disproportionate circumstances ties into more philosophical debates about exploitation. Wertheimer, for instance, considers a situation in which unfair advantage is taken of another person as exploitation. ${ }^{33}$ Goodin takes a vulnerability approach and argues that a person's vulnerability creates obligations vis a vis the vulnerable person. He considers (unusual) advantage-taking behaviour over a vulnerable person to be decisive for the qualification of exploitation. ${ }^{34}$ Sample, 35 critiquing Wertheimer and Goodin, uses the criteria of degrading (disrespectful or harmful treatment) to qualify a situation of exploitation because this better reflects the moral wrongness of the exploitation, an aspect she considers to be absent in the theories of Wertheimer and Goodin. Though worded differently, what is key in all three theories is the taking advantage of a person for one's own benefit and to the detriment of the other person; either by taking unfair advantage, by abusing someone's vulnerability, or by degrading treatment.

31 K. Skrivankova (November 2010), Between Decent Work and Forced Labour: Examining the Continuum of Exploitation, paper for the Joseph Rowntree Foundation, available at: https://www. jrf.org.uk/.

32 D. Mccann and J. Fudge (June 2017), 'Unacceptable forms of work: A multidimensional model', International Labour Review, 156(2), pp. 147-184.

33 A. Wertheimer (1996), Exploitation, Princeton University Press, p. 10.

34 R. Goodin (1985), Protecting the Vulnerable: A Reanalysis of Our Social Responsibilities, University of Chicago Press.

35 R.J. Sample (2003), Exploitation. What It Is and Why It's Wrong, Rowman \& Littlefield, p. 56. 


\section{Control (Including Coercion) as a Condition to Exploitation}

As we have learned from the Chowdury case, control can be both physical control and psychological control. This is also reflected in the means included in the trafficking protocol, which includes force and coercion, but also abuse of power or position of vulnerability, deception, and fraud. In fact, the way control is exercised is not predetermined and can be any act. It is the effect of such an act on the freedom of the person that determines whether it can be considered unfair. In line with Bales and Allain, the exercise of control by a person over another person, because the other person finds him or herself in a position of vulnerability, is relevant to qualifying a situation as exploitative. Control, as well, is a subjective element since it depends on the level of resistance one is able to create, which determines the vulnerability of the affected person (see below).$^{36}$ With more severe forms of control such as violence and coercion, it is reasonable that the person cannot resist the pressure. This, however, might be more difficult to understand in case the control is more subtle, for instance, in case of deception or abuse of vulnerability.

What, in such cases, can be expected from the person in terms of resistance? Although labour standards in a country are helpful, this question cannot be answered in general terms. The position of vulnerability, personal circumstances, the social location, and the social context are all relevant. ${ }^{37}$ Thus, although the element of control the employer has over the worker (including coercion) is an important factor, it needs to be assessed in conjunction with other elements of vulnerability and the broader circumstances of the specific case. Consequently, a situation can be qualified as exploitation even if a person has consented to e.g. exploitative conditions. In such a case, the level of control over the worker might distract consent from its effect, or nullify consent. In the case of Chowdury, the initial consent and the ability to leave the workplace does not hamper the conclusion that this was a case of forced labour and human trafficking.

\section{The Role of Consent in Defining Exploitation}

Following the above, the existence of consent is not a burden for qualifying a situation as exploitation. Translated to the situation of migrant workers,

36 J. Allain and K. Bales (2012), 'Slavery and Its Definition', Global Dialogue, 14(2).

37 D. McCann and J. Fudge (June 2017), 'Unacceptable forms of work: A multidimensional model', International Labour Review, 156(2), pp. 
this observation is highly relevant because, due to a lack of information and often dire economic situations in the home country, migrant workers are often prepared to accept working conditions and payment that are far below the standard in the host country, but nonetheless can be beneficial for the migrant worker. As mentioned above, consent is irrelevant when means (forms of coercion) are used in the process of forced labour and human trafficking. ${ }^{38}$ In other cases in which consent was given, objective indicators are needed to determine whether a situation is exploitative, regardless of the consent given. ${ }^{39}$ Such objective indicators can be found in regulations on compulsory wages, labour conditions, working hours, etc. The level of coercion used can be taken into account when determining the severity of a case. Still, the question remains what the level of deviation from the standard, or minimum rule, is needed to justify the exploitation label. Again, this question needs to be answered taking into account all circumstances of the case, and depends on the national situation and legislation. The ILO indicators for trafficking for the purpose of labour exploitation are helpful to objectify criteria and include e.g. low or no salary, excessive working hours, bad living and working conditions, absence of contract. ${ }^{40}$ Further translation to the national levels is needed for a concrete assessment.

\section{The Role of Vulnerability in Defining Exploitation}

According to the Travaux préparatoires to the Trafficking Protocol, the state of vulnerability 'is understood as referring to any situation in which the person involved has no real or acceptable alternative but to submit to the abuse involved. ${ }^{41}$ This circular reasoning is not very helpful in defining vulnerability. Vulnerability is not a static concept, and the impact of this concept largely depends on the position of the person at risk of exploitation. Gallagher, in her position paper for the UNODC, distinguished between

$3^{8}$ Article 3 (b) of the Palermo Protocol states: (b) The consent of a victim of trafficking in persons to the intended exploitation set forth in subparagraph (a) of this article shall be irrelevant where any of the means set forth in sub paragraph (a) have been used; UNODC Issue Paper (2014), The role of 'consent' in the trafficking in persons protocol, p. 7 .

39 C. Rijken (2015), 'Legal Approaches to Combating the Exploitation of Third-Country National Seasonal Workers', The International Journal of Comparative Labour Law and Industrial Relations, 31(4) pp. 431-452.

40 ILO Operational indicators for trafficking in human beings, available at: http://www.ilo. org/wcmsp5/groups/public/---ed_norm/---declaration/documents/publication/wcms_105023. pdf

41 A.T. Gallagher (2011), The International Law Making of Human Trafficking, Cambridge University Press, p. 32 . 
intrinsic factors linked to the victim, such as age, illness, gender, and poverty, on the one hand, and control factors such as isolation, dependency, and irregular legal status created by the exploiter, on the other hand. ${ }^{42}$ Elsewhere, we suggested to distinguish between internal factors, external factors, and triggers or situational factors. ${ }^{43}$ Vulnerability can consist of more objective elements that represent the external factors, such as poverty, lack of education, and irregular legal status. But not all persons in such a vulnerable situation end up being exploited. The individual circumstances and state of mind - the internal factors - are relevant in creating a heightened risk of vulnerability. There are individualised factors that make people more or less vulnerable, such as an adventurous and thrill-seeking nature, dependence, and level of intelligence. These internal factors elucidate why, in similar circumstances, person A is vulnerable for exploitative practices while person $\mathrm{B}$ is not. Triggers or situational circumstances can also cause vulnerable people to become subject to abuse, for instance, if a potential migrant worker is out of a job in his or her home country and the child of the worker is in need of expensive medical treatment, or the addiction of a spouse causes debts and consequently an acute need for money. It is a combination of these three groups of factors that can cause a toxic mix in which persons become vulnerable to exploitation. The abuse of a situation of vulnerability refers to the act of the exploiter and cannot be justified by the motivations of a person to put himself or herself in the position of vulnerability. For instance, in the Dutch Chinese Restaurant case, the trafficking victims, who were undocumented, had asked to work in the Chinese Restaurant. ${ }^{44}$ The abuse that was made of their vulnerable status as undocumented could not be justified by the fact that they had offered themselves voluntarily, nor by the fact that they had consented to work for eleven to fourteen hours a day for a monthly income of $€ 450$ to $€ 800$, to having only five days off a month, and to sharing bedrooms.

For Hill as well as for Goodin, exploitation and vulnerability are inextricably bound. Reducing ones vulnerability diminishes the risk of being exploited. They recognise that vulnerability is a precondition to exploitation and is defined by Hill as "a disposition of personality or circumstance of

42 UNODC Issue Paper (2012), Abuse of a Position of Vulnerability and other "Means" within the Definition of Trafficking in Persons, Vienna.

43 L. van Waas, C. Rijken, M. Gramatikov, and D. Brennan (2015), Researching the nexus between statelessness and human trafficking. The Example of Thailand, Wolf Legal Publishers, pp. 98-107, 159-163.

44 LJN: BI7099, Supreme Court, 08/03895 
life that serve to hamper the rational-emotive process". ${ }^{45}$ Put differently, all exploited persons are vulnerable in one way or another. However, this does not mean that all vulnerable people are exploited, as was explained above, nor does it mean that vulnerable people are unable to make rational decisions. Poverty or political oppression, for instance, can be qualified as vulnerability factors relevant to exploitation only if being poor or oppressed creates some internal psychological disability affecting the person's capacity to make a decision. Merely qualifying one's vulnerability as relevant for exploitation, without the abuse thereof, would have the effect of victimising people who should not be victimised. ${ }^{4}$

\section{Conclusion}

The question of when bad labour conditions turn into exploitation cannot be answered in general terms. This chapter, however, identified three key factors that play a role in defining the tipping point between the two. These key factors are control (including coercion) over the worker, vulnerability, and consent. Coercion is not a constitutive element for exploitation, but, in a situation in which coercion has been used, exploitation is more easily established. In the same vein, the absence of consent also is not a prerequisite for exploitation. In a consensual situation, objectified criteria can serve as assessment tools for the existence of exploitation, which has to be determined on a case by case basis and by taking into account all aspects relevant to the specific situation.

Having a better understanding of the continuum between bad labour conditions and exploitation and recognising the tipping points and key elements, is a prerequisite for fighting both bad labour conditions and exploitation. The former are more effectively addressed with enforcement of labour standards, while the latter are also to be combatted under criminal law and the protection mechanisms offered to victims of exploitation and trafficking. The question left unanswered in this chapter is whether or not such mechanisms should also be made available for those who have been subjected to bad labour conditions. At the EU level, and specifically in the

45 J.L. Hill (1994), 'Exploitation', Cornell Law Review, 79 p. 686.

46 UNODC Issue paper (2012), Abuse of position of vulnerability and other "means" within the definition of trafficking in persons, 9, pp. 84-86; J. L. Pérez (2015), 'A criminological reading of the concept of vulnerability: A case study of Brazilian trafficking victims', Social and Legal Studies, 25(1) pp. 23-42. 
employers sanction directive ${ }^{47}$ and the seasonal workers directive, ${ }^{48}$ some indications can be found to answer this question in the affirmative.

\section{Bibliography}

Affaire Chowdury et autres c. Grèce, Requête no 21884/15, 30 March 2017.

Allain, J. (2008-2009), 'The Definition of Slavery in International Law', Howard Law Journal, $5^{2}$ pp. 239-266.

Allain, J. (2009), 'R v Tang: Clarifying the Definition of "Slavery" in International Law', Melbourne Journal of International Law, 10(1), pp. 246-257.

Allain. J. and K. Bales (2012), 'Slavery and Its Definition', Global Dialogue, 14(2) pp. 1-8. Anderson, B. (2010), 'Migration, immigration controls and the fashioning of precarious workers', Work, Employment and Society, 24(2) pp. 300-317.

Anderson, B. and J. O'Connell Davidson (2003), Trafficking - A Demand Led Problem? A Multi Country Pilot Study, International Organisation for Migration.

Case of Siliadin v. France, Application no. 73316/01, 26 July 2005 para. 123.

Chang, H.F. (2008), 'The Economics of International Labour Migration and the Case for Global Distributive Justice in Liberal Political Theory', Cornell International Law Journal, 1 pp. 1-27.

Chuang, J.A. (2014), 'Exploitation Creep and the Unmaking of Human Trafficking Law', The American Journal of International Law, 108 pp. 6o9-649.

European Agency on Fundamental Rights (FRA) (2015), Severe Labour Exploitation: Workers Moving within or into the European Union, States'Obligations and Victims' Rights.

Gallagher, A.T. (2011), The International Law Making of Human Trafficking, Cambridge University Press, p. 32.

Goodin, R. (1985), Protecting the Vulnerable: A Reanalysis of Our Social Responsibilities, University of Chicago Press.

Hill, J.L. (1994), 'Exploitation', Cornell Law Review, 79 pp. 631-699.

ILO Operational indicators for trafficking in human beings, available at: http:// www.ilo.org/wcmsp5/groups/public/---ed_norm/---declaration/documents/ publication/wcms_105023.pdf

International Labour Organization (2009), Forced Labour and Human Trafficking. Casebook of Court Decisions. Special Action Programme to Combat Forced Labour. Mccann, D. and J. Fudge (June 2017), 'Unacceptable forms of work: A multidimensional mode', International Labour Review, 156(2), pp.147-184. 
O'Connell Davidson, J. (1 July 2013), 'Troubling freedom: migration, debt, and modern slavery', Migration Studies, 1(2) pp. 176-195.

Ottonelli, V. and T. Torresi (2013), 'When is Migration Voluntary?', International Migration Review, 47(4) pp. 783-813.

Pope, J.G. (2010), 'A Free Labour Approach to Human Trafficking', University of Pennsylvania Law Review, ${ }^{8} 8$ pp. 1849-1875.

Pérez, J.L. (2015), 'A criminological reading of the concept of vulnerability: A case study of Brazilian trafficking victims', Social and Legal Studies, 25(1) pp. 23-42.

Rijken, C. (2015), 'Legal Approaches to Combating the Exploitation of Third-Country National Seasonal Workers', The International Journal of Comparative Labour Law and Industrial Relations 31(4) pp. 431-452.

Sample, R.J. (2003), Exploitation. What It Is and Why It's Wrong, Rowman \& Littlefield, p. 56 .

Skrivankova, K. (November 2010), Between Decent Work and Forced Labour: Examining the Continuum of Exploitation, paper for the Joseph Rowntree Foundation, available at: http://www.jrf.org.uk.

Steinfeld, R. (2009), Coercion/Consent in Labour. Centre on Migration, Policy and Society, Working Paper No. 66, University of Oxford.

Szulecka, M. (2012), 'The Rights to be Exploited: Vietnamese Workers in Poland', in C. van den Anker and I. van Liempt (eds.), Human Rights and Migration. Trafficking for Forced Labour, Palgrave Macmillan.

UNODC Issue Paper (2012), Abuse of a Position of Vulnerability and other "means" within the Definition of Trafficking in Persons, Vienna.

UNODC Issue Paper (2014), The role of 'consent' in the trafficking in persons protocol.

UNODC issue paper (2015), The Concept of 'Exploitation' in the Trafficking in Persons Protocol, pp. 24-26.

Van den Anker, A. and I. van Liempt (eds.) (2012), Human Rights and Migration. Trafficking for Forced Labour, Palgrave Macmillan.

Van Waas, L.; C. Rijken; M. Gramatikov; and D. Brennan (2015), Researching the nexus between statelessness and human trafficking. The Example of Thailand, Wolf Legal Publishers, pp. 98-107, 159-163.

Wertheimer, A. (1996), Exploitation, Princeton University Press.

\section{About the Author}

Conny Rijken is professor of Human Trafficking and Globalisation at INTERVICT, Tilburg University. 